\title{
MID-PALEOZOIC DIMEROCRINITID CRINOIDS FROM NORTH GONDWANA: EVOLUTION, BIOSTRATIGRAPHY AND PALEOBIOGEOGRAPHY
}

\author{
Jean LE MENN ${ }^{\prime}$, Rémy GOURVENNEC ${ }^{l}$, \\ José Manuel PIÇARRA ${ }^{2}$ and Michel ROBARDET ${ }^{3}$ \\ ' UMR 6538 CNRS “Domaines océaniques", Laboratoire de Paléontologie, BP 809, 6 av. Le \\ Gorgeu, 29285 Brest, France. \\ ${ }^{2}$ Instituto Geológico e Mineiro, Ap.104, 7801-902 Beja, Portugal. \\ ${ }^{3}$ Géosciences-Rennes UMR 6118 CNRS, Université de Rennes 1,Campus de Beaulieu, bât. \\ 15, 35042 Rennes, France.
}

Le Menn, J., Gourvennec, R., Piçarra, J.M. and Robardet, M. 2003. Mid-Paleozoic dimerocrinitid crinoids from North Gondwana: evolution, biostratigraphy and paleobiogeography. [Crinoideos dimerocrinítidos del Paleozoico medio del norte de Gondwana: evolución, bioestratigrafía, paleobiogeografía.] Revista Española de Paleontología, 18(1), 49-60. ISSN 0213-6937.

\begin{abstract}
The data set accumulated during the last decade on dimerocrinitid crinoids from the northern margin of Gondwana ranging from Wenlockian to Pragian has been worked out. Two new species, Dimerocrinites aragonensis n.sp. and D. sartensis n.sp., are described. The following evolutionary trends of the theca are evidenced: significant increase of dorsal cup size and plate thickness, smoothening and loss of plate ornamentation, columnal articular development, and related epifacet reduction. The vertical distribution of the Devonian species established in the Armorican sections shows that D. lanveocensis, which originates close to the Silurian/Devonian boundary, may be used for the characterization of the Lower Lochkovian in the IberoArmorican domain. The wide geographical distribution of the dimerocrinitids from South Algeria to the Armorican massif in addition to the robustness of their morphological features, clearly distinct from those of the South Laurussian species, make them paleobiogeographical indicators for the North Gondwanan province. The abundance of dissociated plates and columnals in Lower Lochkovian fine to coarse terrigenous sediments are indicative of proximal paleoenvironments in contrast with the distal open shelf scyphocrinitid biofacies.
\end{abstract}

Keywords: Crinoids, Dimerocrinitidae, Silurian-Lower Devonian, North Gondwana.

\section{RESUMEN}

El propósito de este artículo es presentar una síntesis de los datos recogidos durante los diez ultimos años en diferentes áreas de la provincia nor-gondwánica sobre los crinoideos dimerocrinítidos del Wenlock-Praguiense. Se describen dos especies nuevas : Dimerocrinites aragonensis n. sp. del Wenlock-Ludlow inferior de Aragón (España) y sur de Argelia, y Dimerocrinites sartensis n. sp., del Lochkoviense inferior del Macizo Armoricano francés. Las tendencias evolutivas observadas entre los dimerocrinítidos se manifiestan por el aumento significativo del tamaño de la cápsula dorsal y del espesor de las placas, por la atenuación en la ornamentación y alisado de las placas, y por el desarrollo articular y reducción epifacetal paralela en las placas columnares. La repartición vertical de las especies devónicas, establecida en el Macizo Armoricano, muestra que Dimerocrinites lanveocensis aparece cerca del límite Silúrico-Devónico, y caracteriza el Lochkoviense inferior del dominio ibero-armoricano. La amplia distribución geográfica de los dimerocrinítidos estudiados (desde el sur de Argelia hasta el Macizo Armoricano) y su constancia morfológica, distintiva frente al grupo de especies del sur de Laurrusia, permite considerarlos como buenos indicadores paleogeográficos de la provincia nor-gondwánica. La abundancia de placas y columnales disociadas de dimerocrinítidos, en los sedimentos terrígenos finos y gruesos de las localidades analizadas, se corresponde con la restricción del grupo a paleoambientes proximales, a diferencia de las biofacies con escifocrinítidos que representarían otros paleoambientes más distales propios de la plataforma abierta.

Palabras clave: Crinoideos, Dimerocrinitidae, Silúrico-Devónico Inferior, norte de Gondwana. 


\section{INTRODUCTION}

The existence of dissociated crinoid ossicle-bearing beds in the Lower Devonian has been mentioned in the literature by earlier geologists during the first mapping stage in Portugal and in the Armorican massif. Delgado (1908) was one of the first searchers to pay attention to their usefulness for correlation between dispersed outcrops in the São Mamede area of the Portalegre syncline. A few years later, the same material was assigned to calicinal plates of cystoids by Pruvost (1914). In the Crozon peninsula and in the vicinity of Brest, Collin (1912) observed a level characterized by crinoidal "rings" at the base of the Landévennec Sandstones. The extension of this crinoidal level into the northwestern and central parts of the Armorican massif was established during field studies, but the ossicles were still considered as cystoid plates (cf. Cheirocrinus (Glyptocystites) giganteus) by Pruvost (Pruvost et al., 1946; Delattre et al., 1951). This assigment was based on the plate ornamentation, which shows the same design as in some cystoids, but neither rhombs nor pores have been evidenced on this material. The crinoidal nature of the ossicles and their systematic position were definitely established by the discovery of calices in connection with proximal stem parts in the locality of Las Bruteras (Aragón, Spain). The complete crowns and dissociated columnals belong to the genus Dimerocrinites Phillips (Le Menn, 1985). New occurrences of ossicles have been recognized in a wide geographical domain covering the
Armorican massif, the Iberian peninsula, and North Africa. These ossicles display peculiar morphological features different from those of the South Laurussian taxa. The frequency of columnals in some stratigraphical levels make them markers for stratigraphical correlations in the Lower Devonian. The aim of the present paper is to establish a synthesis of the available data on systematics, evolutionary trends, stratigraphy, and paleogeography of dimerocrinitid crinoids.

\section{SYSTEMATICS}

The Armorican dimerocrinitid crowns occurring in the Lower Pragian have been described in the collective work on L'Armorique Formation (Le Menn, 1980). Later on, the discovery of complete crowns in Aragón was mentioned in a monograph on the Lower and Middle Devonian crinoid faunas from Brittany in order to demonstrate that dissociated columnals and plates belonged to dimerocrinitids (Le Menn, 1985). Two species were left in open nomenclature although they displayed diagnostic characters. Complementary material confirms that they represent new taxa, which are formally defined herein. The studied material and figured specimens are stored in the collection of the Laboratoire de Paléontologie, Université de Brest (LPB) and the museum of the Instituto Geológico e Mineiro de Portugal at Lisbon (IGM).

Figure 1. a-d Dimerocrinites oehlerti Le Menn, 1980. a, conical calyx, A ray in the centre, LPB 5384, x1, Saint-Ouen-desToits (Mayenne), Saint-Céneré Formation (Lochkovian-Pragian); b, conical calyx, CD interray, LPB 5385, x1, same origin as in a; $\mathbf{c}$, fragmentary juvenile aboral cup showing smooth inner surface and pits on radial serie plates, LPB 5383, x2, Pointe de l'Armorique section (S92), Plougastel-Daoulas (Finistère), l'Armorique Formation (Lower Pragian); d, bowl-shaped calyx, CD interray on the right, LPB5386, x1.25, La Baconnière (Mayenne), Saint-Céneré Formation (Lochkovian-Pragian). e-i Dimerocrinites lanveocensis Le Menn, 1985. e, latex mold of an isolated nodal, LPB 9595A, x2, La Boë, Gahard (Ille-et-Vilaine), Gahard Formation (Lochkovian); f, latex mold of an isolated nodal, LPB 9589D, x2, Anse du Poulmic, Lanvéoc (Finistère); g, internal mold of an isolated plate (IBr probably) showing well developed ridges and furrows, LPB 11051, x1.5, Fort de Lanvéoc section, Lanvéoc (Finistère), Landévennec Formation (Lochkovian); h, internal mold of an isolated plate (IiR or IAn), LPB11053, x1.5, Kerzivez, Plougastel-Daoulas (Finistère), Landévennec Formation (Lochkovian); i, internal mold of a fragmentary aboral cup (R to IIBr2), holotype LPB 9587, x1, origin as in g. j-p Dimerocrinites aragonensis Le Menn, n. sp. j, latex mold of a fragmentary calyx and proximal part of the column, LPB 9581C (left), Las Bruteras (Aragón, Spain), Bádenas Formation (S3da, Upper Wenlock - Lower Ludlow); k, latex mold of two calices, holotype on the right showing CD interradius, holotype LPB9581A (right) and LPB 9581B (left), same origin as in j; $\mathbf{l}$, latex mold of an isolated nodal, note the reduced articular facet, LPB 11057, x2, same origin as in j; $\mathbf{m}$, internal mold of an isolated plate showing well developed ridges and furrows, LPB $11059, \mathrm{x} 2.5$, same origin as in $\mathrm{j}$; $\mathbf{n}$, isolated small columnal from proximal part of the stem, LPB 11061, x2.5, Aouinet Bel Egraa section (ABE 1, Algeria), "Dalles à encrines", Gara Djebilet Formation (Upper Wenlock-Lower Ludlow), o, isolated nodal, LPB 11062, x1.5, same origin as in n; p, latex mold of an isolated nodal, note the reduced articular facet, LPB 11058, x2, same origin as in j. q-v Dimerocrinites sartensis Le Menn, n. sp. q, latex mold of an isolated plate showing sharp ornamentation, LPB 5184B, x3, motorway trench Le Mans-Paris, bridge South of Les Loges village, Saint-Denisd'Orques (Sarthe). Gahard Formation (Lochkovian); r-s, internal cast of the plate showing smooth inner surface and latex mold of the external surface with an ornamentation of sharp crests, holotype LPB 5184A, x2.5, same origin as in $\mathrm{q}$; $\mathbf{t}$, natural cast of an articular facet with developed perilumen, LPB 5182A, x5, same origin as in q; $\mathbf{u}$, latex mold of an isolated nodal, note the development of articular facet and faint crenulae, LPB 5181B, x3.5, same origin as in q; $\mathbf{v}$, latex mold of an isolated columnal with lobate lumen, LPB 5181A, x 5, same origin as in q. 

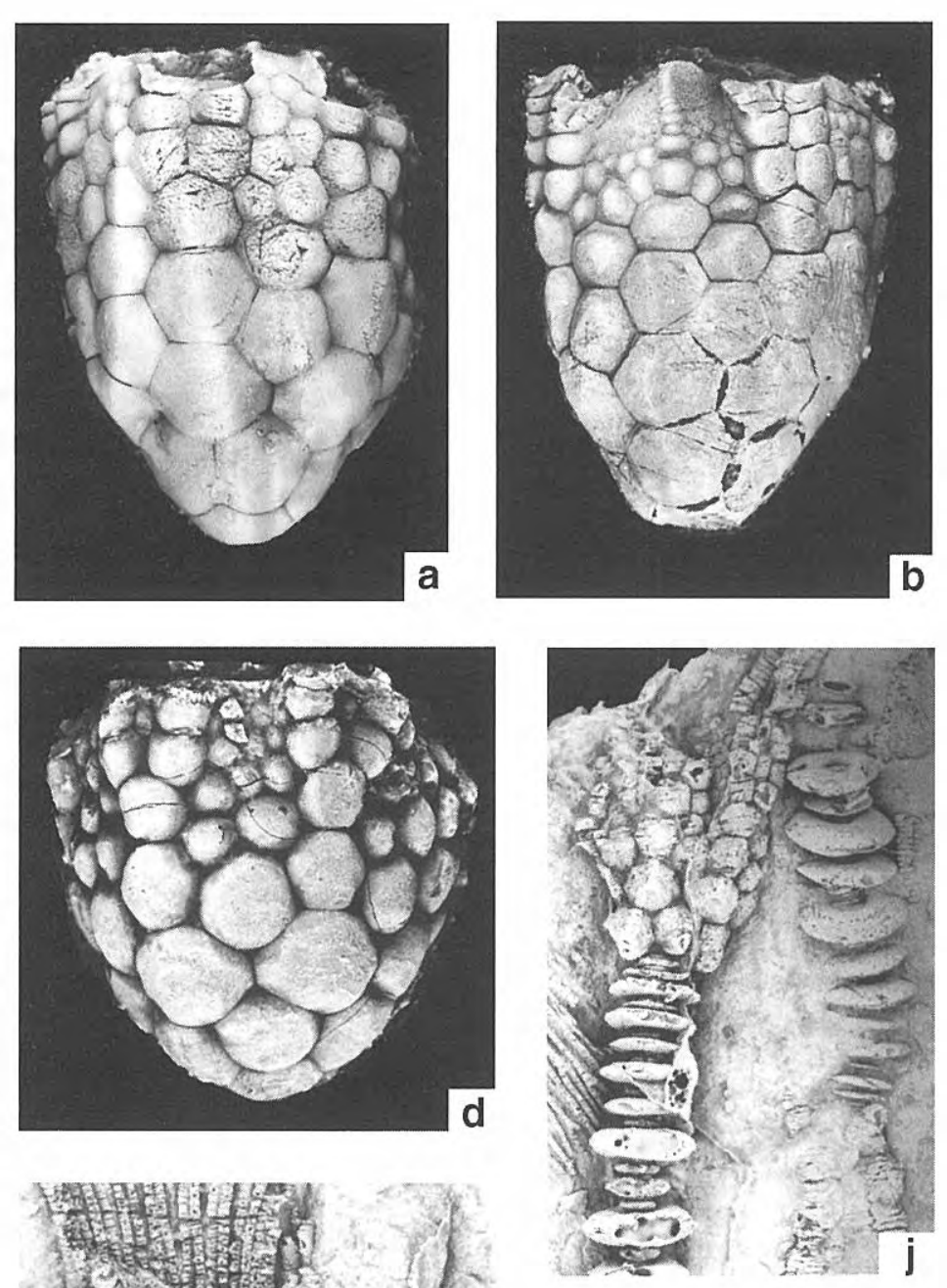

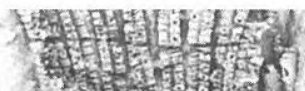
130 . 19.

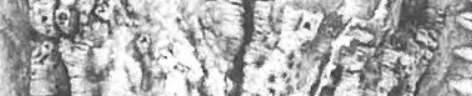

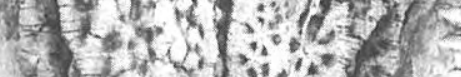

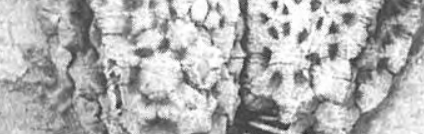

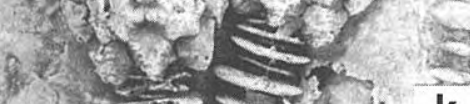
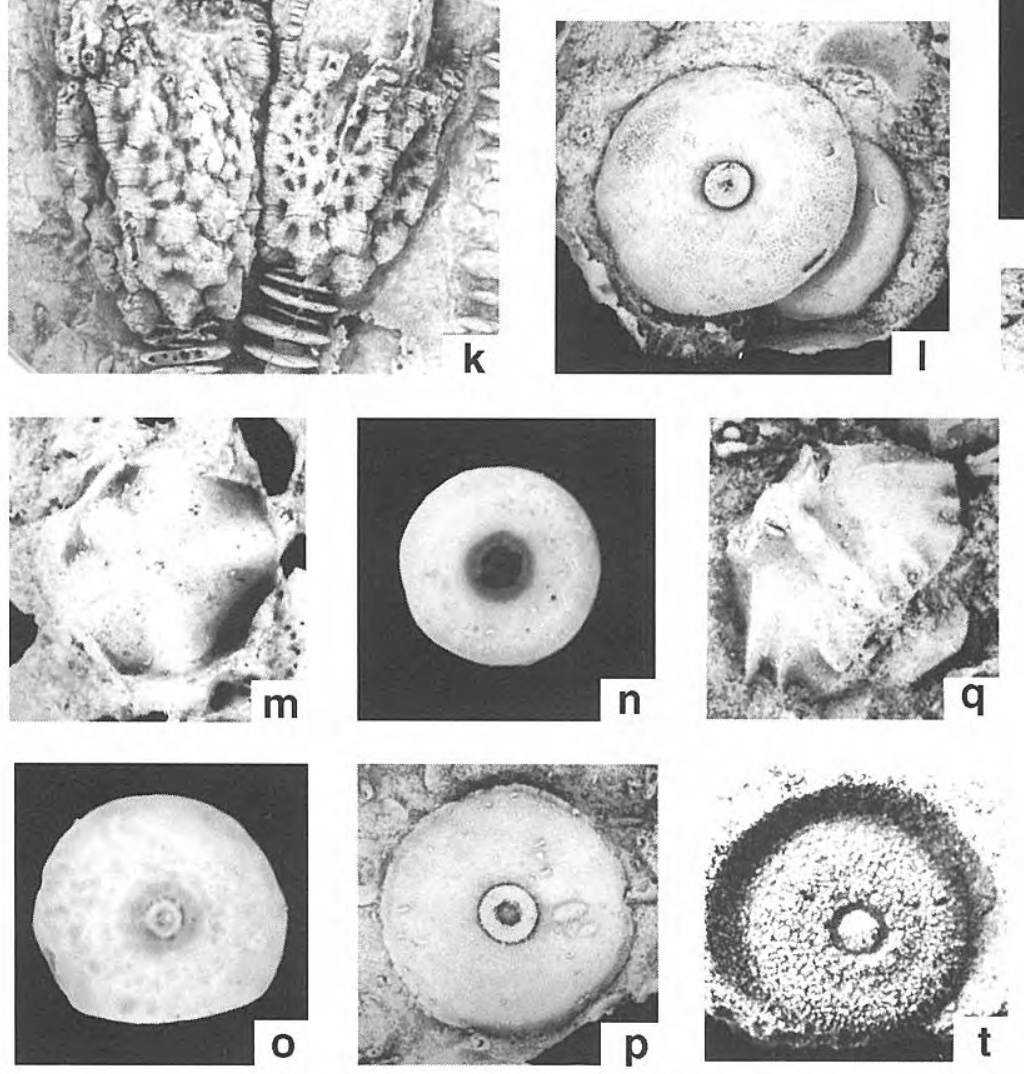
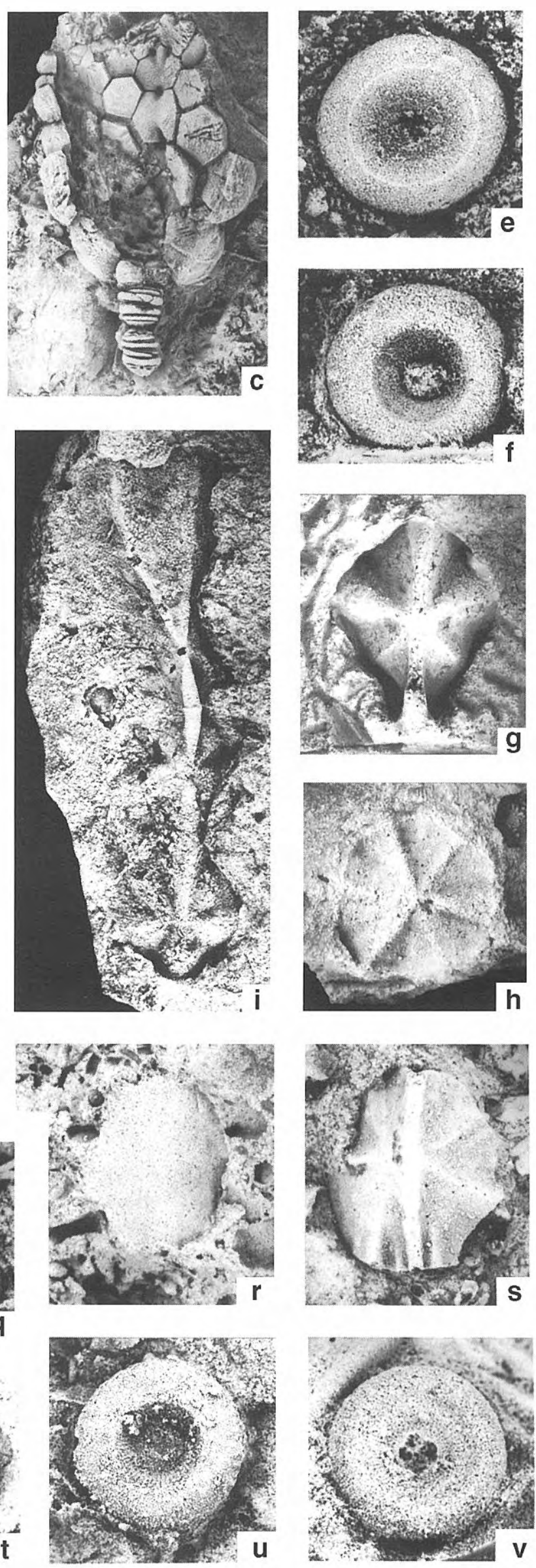
SUBCLASS CAMERATA Wachsmuth and Springer, 1885

ORDER DIPLOBATHRIDA Moore and Laudon, 1943

Superfamily Dimerocriniticea Zittel, 1879

Family Dimerocrinitidae Bassler, 1938

Genus Dimerocrinites Phillips, 1839

Type species: Dimerocrinites decadactylus Phillips, 1839.

The dimerocrinitid taxa from the north Gondwanan Silurian and Lower Devonian may be readily identified on both their dissociated cup plates and columnals. The main diagnostic characters for plates are the external ornamentation, internal furrows, size and thickness. During this time interval, columnals underwent also changes by modifications of the ratio between articular structures and epifacetal development.

\section{Dimerocrinites aragonensis Le Menn, n. sp.} Fig. 1 j-p, 2A, 3-4.

1985 Dimerocrinites sp. A Le Menn, 47-48, Fig. 19, pl. 6, fig. 1-8.

1987 Dimerocrinites sp. A Le Menn; Le Menn, 817, pl. 1, fig. 15-16, 19.

Derivation of name: from the name Aragón (Spain).

Holotype: crown in external and internal mould LPB 9581A figured in Le Menn (1985, pl. 6, fig.1a-1b, Fig.19); present note, Fig. 1k. Las Bruteras section, Luesma, Aragón (Spain); Bádenas Formation (S3da), Upper Wenlock-Lower Ludlow.

Figured specimens (in Le Menn, 1985): partial crowns: LPB 9581A-B, pl. 6, fig. 1a-b; stem fragments: LPB 9579, pl. 6, fig. 6; LPB 9580, pl. 6, fig. 2; isolated columnals: LPB 9582A, pl. 6, fig. 5; LPB 9584A, pl. 6, fig. 4; LPB 9586B, pl. 6, fig. 3, LPB 9586C, pl. 6, fig. 8; LPB 9586D, pl. 6, fig. 7.

Material: 3 crowns, 3 stem fragments, hundreds of isolated columnals.

\section{Diagnosis}

Theca of medium to large size; calyx with weakly divergent sides; thick plates bearing a radial ornamentation of coarse ridges perpendicular to the sutures; internal surface of plates provided with furrows; basals tuberculated. Rays and interrays having a typical dimerocrinitid composition and arrangement (Fig. 2A). Rays composed of 2 primibrachials and 2 secundibrachials; 20 biserial arms, free above $5^{\text {th }}$ to $7^{\text {th }}$ tertibrachials, bearing dense and long pinnules. Stem strongly heteromorphic with a wide, rounded to flat epifacet, epifacetal index: 76-81; internodes comprising 5 cycles of columnals; articular facet seemingly smooth.

\section{Discussion}

D. aragonensis $\mathrm{n}$. sp. presents global affinities with several species from the Silurian of Gotland, Wales, and
New York, especially with $D$. quinqueangularis (Angelin). However, it shows peculiar characters: larger size, thick and developed radial ornamentation, strongly heteromorphic stem, considered as being of specific level, which justifies the definition of a new taxon. The Lower Devonian D. lanveocensis Le Menn is distinguished from the new species in having a huge size and a more developed articular facet on the columnals. The values of the articular facet and facet indices are clearly separated on the scatter diagrams (Fig. 4). The columnals collected in the sections of the southern border of the Tindouf basin (Algeria) are assigned to D. aragonensis n.sp. on the values of their facetal and epifacetal indices. They are very close to those of the Bádenas Formation from Aragón, but differ in having a slightly higher ratio for the facet and subsequently a lower value for the epifacet (Fig. 4). If we agree that the general evolutionary trend corresponds to an increase of the articular structure and a reduction of the epifacet, the Algerian specimens are considered to be somewhat younger than the Aragonese material. The broken columnals from Tindouf present a dark sheet in the median plane which is clearly visible on the section on most specimens. The vertical sections in a few specimens show that the sheet is due to impregnation of iron oxide in the median plane (Fig. 3). The secondary crystallisation of the calcite does not allow any observation of the microstructure of the columnals. A few specimens collected in the so-called "banc à Chonetes " in the Ougarta Mountains are assigned to the new species according to their facetal and epifacetal indices. A specimen with a flat and wide epifacet exhibits a dissymmetrical growth provided by short digitated expansions of the outer margin. These outgrowths may be involved in an anchoring function.

\section{Distribution}

Upper Wenlock - Lower Ludlow. Bádenas Formation (S3da), Las Bruteras, Aragón, Spain. "Dalles à encrines", Gara Djebilet Formation, Gara Djebilet West section (GDO 1), Aouinet Bel Egraa section (ABE 1), Algeria. "Banc à Chonetes", Ougarta Mountains, El Kseib section, Algeria.

\section{Dimerocrinites lanveocensis Le Menn, 1985}

Fig. 1e-i, 2B

1972 Crinoid ossicles; Renouf, pl. 26, fig. 14-15.

1985 Dimerocrinites lanveocensis n. sp.; Le Menn, 49, pl. 6, fig. 9-14.

1987 Dimerocrinites lanveocensis Le Menn; Le Menn, 817, Fig. 7; pl. 1, fig. 17.

1992 Dimerocrinites lanveocencis Le Menn; Plusquellec, 15-16.

Material: 1 fragmentary aboral cup; numerous dissociated plates and columnals from the Armorican massif and Portugal.

\section{Description}

Very large species with plicated cup plates bearing 


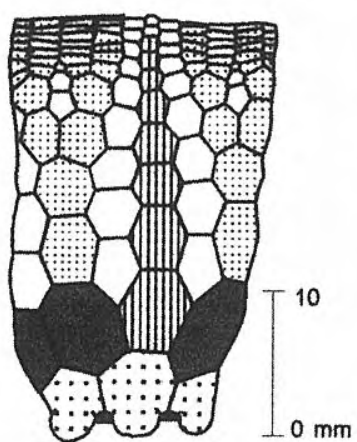

A

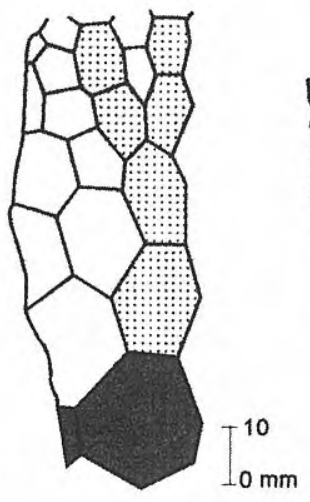

B

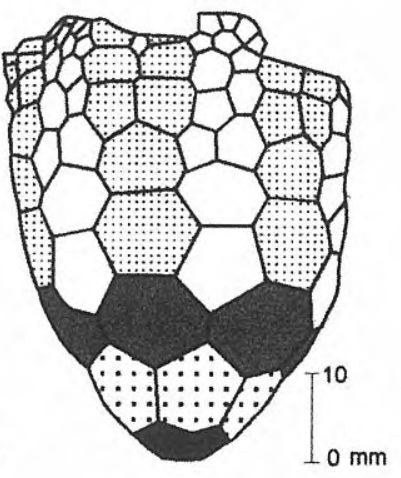

C

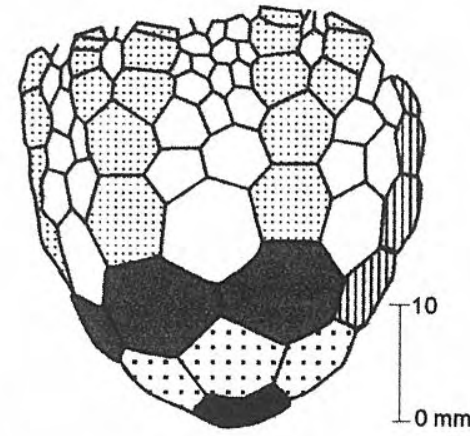

D

Figure 2. Plate diagrams of dorsal cups. A: D. aragonensis n. sp., holotype in CD interray view (LPB 9581A); B: D. lanveocensis, partial cup, holotype (LPB 9587); C: D. oehlerti, conical cup with A ray in the centre of the cup (LPB 5384); D: D. oehlerti, bowlshaped cup CD interray on the right (LPB 5386). Black: infrabasals; heavily stippled: basals; shaded: radials; finely stippled: fixed brachials; ruled: anals; white: interradials and interbrachials.

external ridges radiating from the center of the plates and perpendicular to the sutures; furrows are present on the inner surface corresponding to the external ridges. Isolated plates may be identified after the partial cup of the holotype, especially the hexagonal to heptagonal elongated fixed brachials with convexity increasing strongly on the two secundibrachials; hexagonal to heptagonal large plates with low relief may be identified as radials or first interradials. Columnals with an articular facet provided with very fine crenulae; epifacet still developed but narrower than the facetal diameter; mean of epifacetal index: 37.

\section{Discussion}

The isolated cup plates were first assigned to cystoids by earlier geologists on their shape and their ornamentation, but neither pores nor rhombs have been observed (Pruvost, 1914; Delattre et al. 1951). Most of the material from old collections is assigned to $D$. lanveocensis Le Menn, but some large thin hexagonal plates with narrow angular ridges separated by a granular ornamentation belong probably to another camerate. $D$. aragonensis $\mathrm{n}$. sp. and D. lanveocensis Le Menn show close affinities. They are distinguished by the larger size and the more developed articular facet on the columnals in the latter species. D. oehlerti Le Menn differs considerably from $D$. lanveocensis Le Menn by its smooth and convex calyx plates and a reduced epifacet on the nodals.

\section{Distribution}

Isolated columnals and cup plates occur in numerous localities throughout the Armorican massif so that the list is too long to be fully mentioned here; only the reference and type sections will be cited here. In the western part (Finistère): top of the Plougastel Formation and lower part of the Landévennec Formation, Lower Lochkovian; East section of the Fort de Lanvéoc (Lanvéoc), Corbeau, Caro, and Penn Beleg sections (Plougastel-Daoulas). In the central and eastern parts of the Armorican massif: base of the Gahard Formation, Lower Lochkovian; 1'Arlay near Saint-
Gilles-Vieux-Marché (Côtes d'Armor); La Boë section, Gahard (Ille-et-Vilaine); Chapelle Saint-Sylvain section, Saint-Pierre-sur-Erve (Mayenne). In Normandy: lower part of La Haye-du-Puits Formation, Lower Lochkovian; SaintGermain-sur-Ay section (Manche). In Portugal, the species has been identified in Delgado's collection from the Lower Devonian sandstones ("Grès superiores") from São Mamede region, Portalegre syncline. It has been collected also in the sandstones of the lower member of the Telheiras Formation in São Félix de Laundos section, Valongo syncline.

\section{Dimerocrinites sartensis Le Menn, n. sp. Fig. 1q-v}

1985 Dimerocrinites sp. B, Le Menn, 51, pl. 7, fig. 6-11. 1987 Dimerocrinites sp. B, Le Menn, 817, pl. 1, fig. 18.

Derivation of name: from the Sarthe department (East of the Armorican massif).

Holotype: isolated plate LPB 5184A, figured in Le Menn (1985: pl. 7, fig. 6). Motorway trench Le Mans-Paris, bridge South of Les Loges village, Saint-Denis-d'Orques (Sarthe). Gahard Formation, Lochkovian.

Paratype: isolated columnal LPB 5181B, figured in Le Menn (1985: pl. 7, fig. 9).

Material: 11 isolated cup plates, 52 columnals.

\section{Diagnosis}

Calice plates bearing an ornamentation of narrow sharp ridges and smooth inner surface; columnal articular facet with a well differenciated perilumen surrounded by fine crenulae.

\section{Description}

Internal moulds of isolated plates clearly show the lack of furrows on the inner surface (Fig. 1r); external ornamentation 


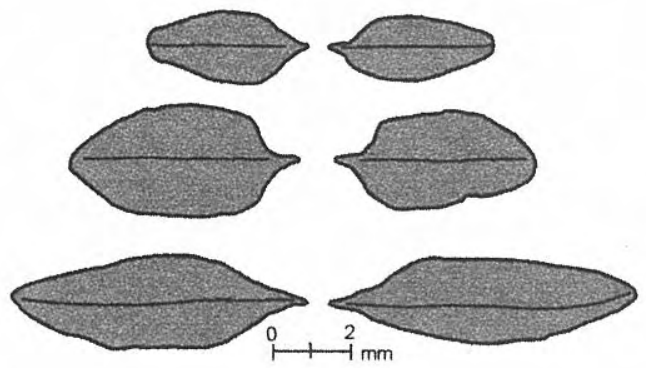

Figure 3. D. aragonensis n. sp., vertical sections of columnals showing the morphological changes in the profile of columnals from proximal (top) to distal (bottom). Note the dark line in the middle plane of the columnals.

composed of narrow sharp ridges radiating from the center of plates and perpendicular to the sutures; secondary short ribs are present on some specimens. Columnal provided with a developed epifacet, more reduced than on D. lanveocensis Le Menn; mean of epifacetal index: 30; articular facet with a narrow well- individualized perilumen (Fig. 1t-v); articulum extending from the perilumen to the epifacet covered by fine and numerous crenulae.

\section{Discussion}

The revision of the dissociated plates and columnals points out some distinctive features, which are considered of specific level. Plates ornamentation, absence of inner furrows, and perilumen distinguish the new species from the earlier D. aragonensis n. sp. and D. lanveocensis Le Menn. The Lower Pragian D. oehlerti Le Menn shows smooth convex calicinal plates with a very reduced epifacet on the columnals.

\section{Distribution}

Laval syncline: Gahard Formation, Lower Lochkovian; motorway section South of Les Loges, Saint-Denisd'Orques (Sarthe). Normandy: La Haye-du-Puits Formation, Lower Lochkovian, Saint-Germain-sur-Ay section (Manche). South-Eastern Armorican massif: "Platyorthis sandstone"; Saint-Barthélémy quarry, Chaufour (Maine-etLoire).

\section{Dimerocrinites oehlerti Le Menn, 1980}

\section{Fig. 1a-d}

1980 Dimerocrinites oehlerti n. sp.; Le Menn, 249, pl. 34, fig. 9-10.

1985 Dimerocrinites oehlerti Le Menn; Le Menn, 52, pl. 7, fig. 1-5.

1987 Dimerocrinites oehlerti Le Menn; Le Menn, 817, pl. 1, fig. 20.

Material: 6 dorsal cups.

\section{Description}

Large sized species with two morphotypes present in the material:
- conical aboral cups having a prominent infrabasal circle without differentiated articular stem facet,

- bowl-shaped aboral cups provided with low infrabasal and normal articular facet for the stem.

Cup plates thick, strongly convex, smooth or with very weak ridges on the rays. Lower plate cycles $(\mathrm{BB}, \mathrm{RR}, \mathrm{Ibr}$, IiR) considerably larger and taller than the following cycles, giving a stout architecture of the cup base on the bowlshaped morphotype (Fig. 2 C-D). Inner surface of the plates lacking furrows excepted on radials and fixed brachials which bear also deep pits on the upper and lower sutures. Infrabasals tuberculated on the holotype. Anal serie well differentiated; upper interradials and interbrachials very convex to hemispheric. Tegmen composed of numerous small, thick plates. Proximal part of arms preserved; arms free above secundibrachs 5 to 9 , branching one time above secundibrachs 9 to 15 . Heteromorphic stem composed of circular columnals provided with a reduced epifacet, epifacetal index: 20; articulum unknown.

\section{Discussion}

D. oehlerti Le Menn differs from D. lanveocensis Le Menn in having a smaller size, smooth cup plates, and a reduced epifacet on the columnals. The discrimination between $D$. oehlerti Le Menn and D. sartensis n. sp. is based on the ornamentation composed of narrow sharp ridges on cup plates and a developed columnal epifacet in the new species.

\section{Distribution}

L'Armorique Formation, Lower Pragian; Pointe de l'Armorique south section (S92); Plougastel-Daoulas. The specimens from the Laval syncline have been collected by earlier workers so that their position in the formation is not precisely known. Saint-Céneré Formation, Upper Lochkovian-Lower Pragian; La Baconnière and Saint-Roch quarry, Saint-Ouen-des-Toits, Mayenne.

\section{EVOLUTIONARY TRENDS}

Previously described morphological changes (Le Menn, 1985, 1987) are corroborated and emphasized by the newly collected North African and Iberian material. Some bias still remains in the fossil record of the lineage during the Ludlow-Pridoli time interval. Nevertheless, three main trends are evidenced in the evolution of the theca: size increase of the aboral cup, ornamentation of plates, and the strengthening of the calyx base.

The Aragonese species shows a greater size than the taxa occurring in the Baltic and Laurentian Silurian as pointed out in the comparisons of the systematic study. A considerable size increase is observed between the lower Ludlow D. aragonensis n. sp. and the lower Lochkovian D. lanveocensis. The latter is represented only by fragmentary cups or isolated plates and columnals, but measurements of radial rays reveal that the size has been magnified by a factor 4 . The maximum size is reached in this species with aboral cup height estimated at more than $100 \mathrm{~mm}$ or isolated cup plates ranging up to $25 \mathrm{~mm}$. Size 

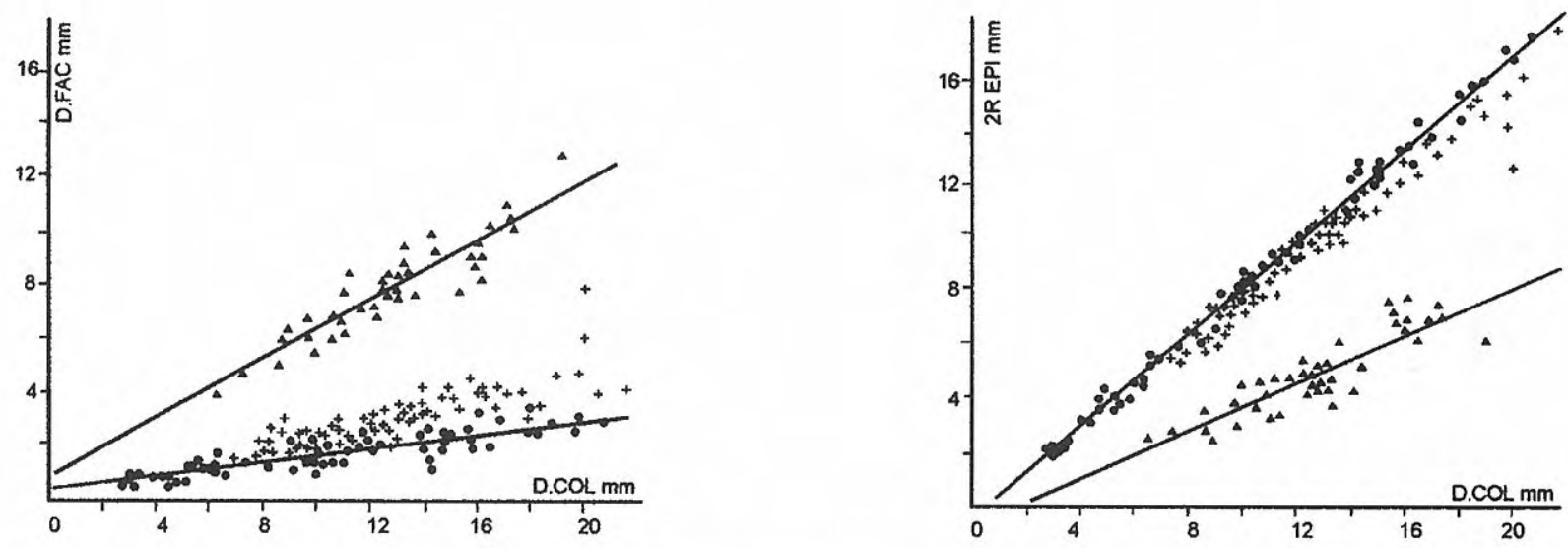

Figure 4. Scatter diagrams of dissociated columnal measures showing well separated values. D.FAC: facetal diameter, D.COL: columnal diameter; 2R EPI: width of the epifacet x 2. Triangle: $D$. lanveocensis; point: specimens of $D$. aragonensis n. sp. from Aragón; cross: specimens of D. aragonensis n. sp. from Tindouf.

reduction took place later in $D$. sartensis $\mathrm{n}$. sp. and in $D$. oehlerti, but the two species retained a large size.

This trend is followed also by modifications of the plate thickness and ornamentation. The cup plates of $D$. aragonensis $\mathrm{n}$. sp. are covered by ridges radiating from a central tubercle and perpendicular to the sutures. The angles of plates between the ridges are strongly depressed. On the inner surface, furrows corresponding to the external ridges are present so that isolated plates have a plicated aspect in transversal plane. Sections through natural molds of isolated plates show an unusual thickness in D. aragonensis n. sp. As a result of the significant size increase in $D$. lanveocensis, the ornamentation becomes less prominent; ridges are wider, rounded, separated by weakly depressed areas. In $D$. sartensis $\mathrm{n}$. sp., marked changes occur on the inner surface, where the furrows are not differentiated except for the median groove on the ray plates. The inner surface of the interradials and brachials is concave and smooth (Fig. 1r). The plate thickness also is decreased so that the narrow and sharp ridges on the external surface are superficially rooted on the plates. The absence of furrows on the inner surface of the plates is also retained in $D$. oehlerti and the external ornamentation has almost completely disappeared; only some specimens show weakly depressed angles of the plates in the lower cycles and a very faint ridge on the rays. On some other cups the plates are strongly convex with deep sutures (Fig. 1d).

The third trend concerns the general design of the cup evidenced by the comparison between $D$. aragonensis $\mathrm{n}$. sp. and D. oehlerti (Fig. 2). The older species has a cup composed of plates in which size decreases regularly from the basal to the oral face. The cups look like a puzzle in which only the ridges of the radial series are marked. In D. oehlerti, the base of the cup shows a stronger constitution in which the lower cycles (basals, radials, first primibrachials, and first interradials) are larger and stouter. Above the level of the suture between the two first primibrachials, the interradials become considerably smaller. The ratio height from the base to the upper suture of first primibrach versus height of the cup from base to the top of the second secundibrachials (the most usual case of preservation) has been calculated for the two species. Although the data set is limited, it corroborates the observations. The ratio ranges from 0.50 to 0.60 for D. aragonensis $\mathrm{n}$. sp. $(\mathrm{N}=3)$ and from 0.65 to 0.78 for D. oehlerti $(\mathrm{N}=6)$.

The columnals also underwent significant morphological and functional changes from the Upper Wenlock to the Lower Pragian. Based on measurements and indices, the most evident trend is the development of the articular facet followed by the reduction of the epifacet (Fig. 5). The very wide epifacet of D. aragonensis n. sp. represents more than $75 \%$ of the columnal diameter. The articular facet is reduced to a deep cavity seemingly devoid of crenulae. They have been observed neither on the natural molds of the Spanish material nor on the calcitic specimens from Tindouf, which are well preserved in red shales. The increase of the articular facet diameter is marked in D. lanveocensis by a turn-over of index values, which are higher for the facet than for the epifacet. On the specimens preserved in fine grained sandstones, the articulum appears to be covered by very faint and straight crenulae. The next step represented by $D$. sartensis $\mathrm{n}$. sp. shows that the epifacet is reduced to a narrow rim with a convex latus and, for the first time, a well-differentiated perilumen appears surrounded by faint crenulae (Fig. 1tv). The most advanced stage is found in $D$. oehlerti where the epifacet has regressed significantly, but it is still differentiated (Fig. 1c). In the Pragian species the articular structures remain unknown.

The lineage of the North Gondwanan dimerocrinitids displays significant evolutionary trends from the Upper Wenlock to the Lower Pragian. The data set obtained on the evolution of the different parts of the cup and the columnals make this group available for stratigraphical purposes.

\section{BIOSTRATIGRAPHY}

The dimerocrinitid isolated columnals and plates are found mostly in coquina beds or condensed levels in the stratigraphical interval ranging from the Wenlock to the 


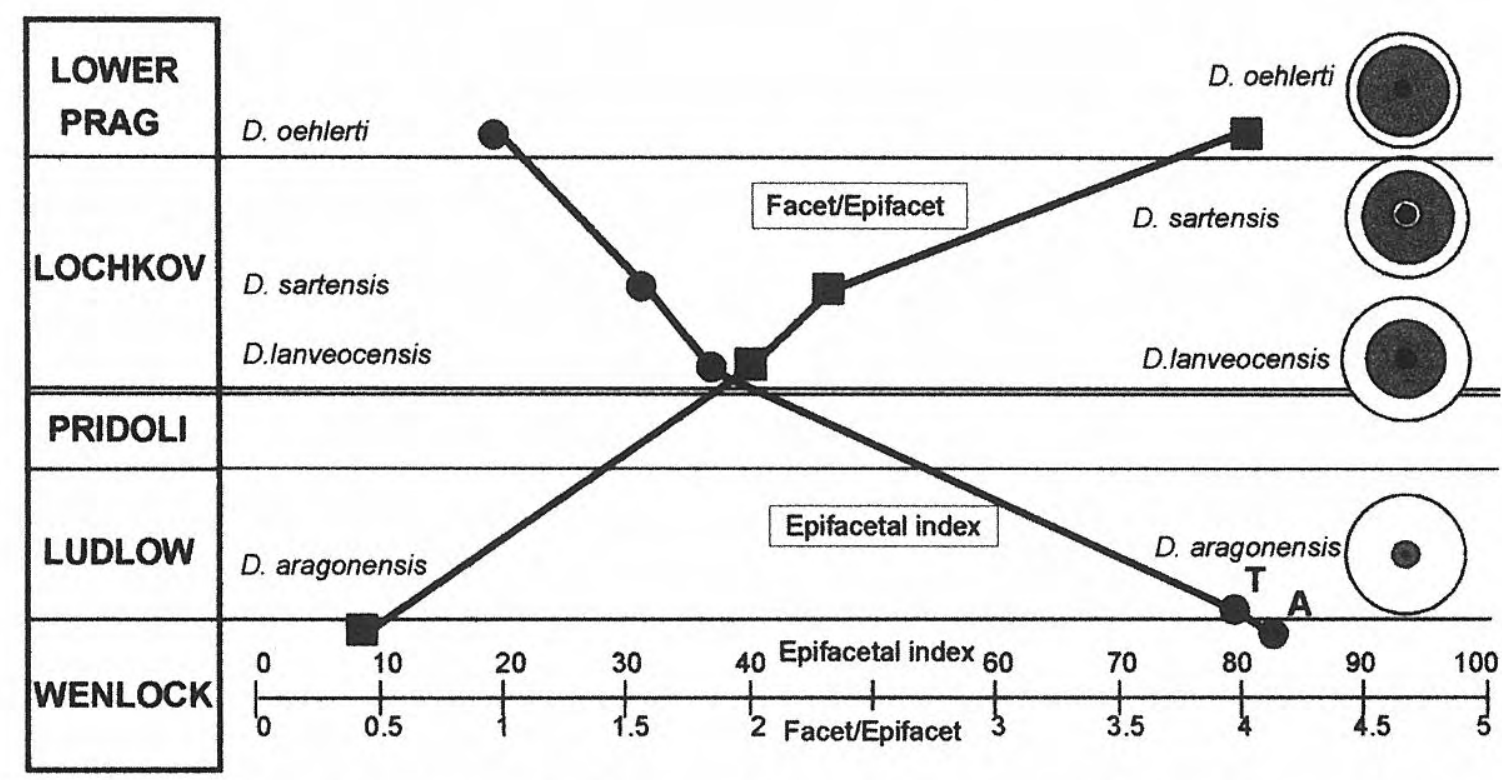

Figure 5. Diagram showing the reduction of the epifacet and the development of the facet. Points: epifacet index (2R Epi/Dcol x 100); square: facet/epifacet ratio (2R Epi/D.fac). D. aragonensis n. sp.: A specimens from Aragón, T specimens from Tindouf.

Pragian. They are associated with terrigenous lithofacies of coarse- to medium-grained sandstones on the northern margin of Gondwana extending from the southern flank of the Tindouf basin through the Iberian peninsula to the Armorican massif. Occurrences of scattered specimens in the sandstone formations are less frequent so that the record of the dimerocrinitids in the Silurian-Devonian successions appears somewhat discontinuous. Nevertheless, the levels characterized by a high amount of dimerocrinitid ossicles are of great help for age determination and correlations in non-graptolitic facies.

The vertical distribution and the correlation are summarized on Fig. 5-6. The oldest species, $D$. aragonensis $\mathrm{n}$. sp., has been recorded for the first time in the Bádenas Formation in the Eastern Iberian chains (Carls, 1965). This marker bed in the thick terrigenous sequence is located above the middle part of the formation. The fossil assemblage comprises mostly crinoid ossicles, gastropods, leiopterid bivalves, and some scarce brachiopods. The age of this level has been discussed by Carls $(1965,1971,1977)$ and is assumed to be Upper Wenlock to lowermost Ludlow. In the southern limb of the Tindouf basin the accumulation of the crinoid ossicles in red shales with ironstone constitues the so called "dalle à encrines" of Gévin (1960) who assigned them to cf. Gennaocrinus. This author considered the level as the base of the Devonian. The study of the graptolitic fauna by Legrand (1969) led to the conclusion that the occurrence of Monograptus priodon priodon in the strata below the crinoid bed belongs to the Wenlock. The preliminary results on the crinoid columnals corroborate this age (Bitam et al., 1996). The analysis of the biometric data in the present work shows that the specimens from the Tindouf area have a facet/epifacet ratio slightly higher than the material from Las Bruteras so that the Algerian crinoid bed is probably younger and an early Ludlow age may be retained for this layer. In the
Ougarta Mountains the specimens assigned to $D$. aragonensis $\mathrm{n}$. sp. have been collected in the "chonetid level". The outcroup is close to the El Kseib section, but separated by a gap so that the age of the "chonetid bed" has not been established in the global study of the macroand microfossils of the Ougarta region (Boumendjel et $a l ., 1997)$. It may be correlated to the "dalles à encrines" of the Tindouf area.

The Lower Devonian in the Ibero-Armorican domain frequently yields large columnals and plates in the detrital sedimentation also associated with condensed ferruginous and phosphatic layers. These isolated ossicles assigned to D. lanveocensis have been collected throughout the Armorican massif from the western Crozon peninsula to the eastern limit of the Laval syncline and from Normandy in the North to the Angers area in the SouthEast. The species occurs in the sandstone formations ranging from the Upper Pridoli to the base of the Upper Lochkovian.

The most suitable sections for biostratigraphical purposes have been investigated in the Rade de Brest for the Western part of the Armorican massif. Le Corbeau, le Caro, and Penn Beleg sections (Plougastel-Daoulas) expose a complete succession through the upper Plougastel and lower Landevennec Formations (Fig. 6). They have been investigated for the Silurian/Devonian limit. The upper part of the Plougastel Formation is composed of upward- thinning alternations of shales/silts and quartzites containing phosphatic pebbles and thin condensed layers with ferruginous crusts. This environment is very poor in benthic fauna; scarce brachiopods and crinoids are present in the top of the formation. Columnals of D. lanveocensis are present in the uppermost metres of the formation (3.5 meters below the limit) together with Howellella mercurii and Platyorthis monnieri, which appear earlier than the crinoids, 12 metres below the upper limit of the 


\begin{tabular}{|c|c|c|c|c|c|c|}
\hline STAGES & $\begin{array}{l}\text { CRINOID } \\
\text { RANGE }\end{array}$ & $\begin{array}{l}\text { SPIRIFERID } \\
\text { ZONES }\end{array}$ & $\begin{array}{l}\text { CHITINOZOAN } \\
\text { ZONES }\end{array}$ & WESTERN ARMOR. & EASTERN ARMOR. & NORMANDY \\
\hline $\begin{array}{l}\text { LOWER } \\
\text { PRAGIAN } \\
\end{array}$ & & Hysterolites gandli & Angochitina comosa & \multirow{3}{*}{$\begin{array}{l}\text { L'ARMORIQUE } \\
\text { Formation }\end{array}$} & \multirow{3}{*}{$\begin{array}{l}\text { SAINT-CENERE } \\
\text { Formation }\end{array}$} & \multirow{3}{*}{$\begin{array}{l}\text { NEHOU } \\
\text { Formation }\end{array}$} \\
\hline \multirow{5}{*}{$\begin{array}{l}z \\
\frac{2}{3} \\
0 \\
\frac{1}{1} \\
0 \\
0\end{array}$} & \multirow{5}{*}{ 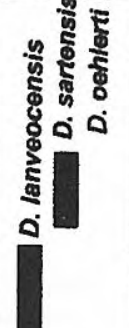 } & \multirow{2}{*}{ Howellella cartsi } & Urochitina simplex & & & \\
\hline & & & Fungochitina lata & & & \\
\hline & & Howellella cortazari & \multirow{3}{*}{ Eisenackitina bohemica } & \multirow{3}{*}{$\begin{array}{c}\text { LANDEVENNEC } \\
\text { Formation }\end{array}$} & \multirow{3}{*}{$\begin{array}{l}\text { GAHARD } \\
\text { Formation }\end{array}$} & \multirow{3}{*}{$\begin{array}{l}\text { LA HAYE-DU-PUITS } \\
\text { Formation }\end{array}$} \\
\hline & & Howellella knetschi & & & & \\
\hline & & Howellella mercurii & & & & \\
\hline $\begin{array}{l}\text { UPPER } \\
\text { PRIDOLI }\end{array}$ & & & Umochitina uma & $\begin{array}{l}\text { PLOUGASTEL } \\
\text { Formation }\end{array}$ & LE VAL Formation & $\begin{array}{l}\text { SAINT-GERMAIN- } \\
\text { SUR-AY Formation }\end{array}$ \\
\hline
\end{tabular}

Figure 6. Stratigraphical distribution of dimerocrinitid species in the Lower Devonian.

formation. Columnals and isolated plates are frequently found in the basal sandstones and quartzite of the overlying Landévennec Formation (Kerdeniel Member), which contains a more diversified benthic fauna with brachiopods, bryozoans, tabulate corals, and trilobites. The most significant taxa in the assemblage and also for stratigraphical correlations are the brachiopods Howellella mercurii and Platyorthis monnieri. The isolated columnals and plates of $D$. lanveocensis seem restricted to the lower member in which they are found together with the first representative of the genus Diamenocrinus sp. A. The investigations on palynomorphs and chitinizoans carried out in these formations (Deunff, 1980; Deunff and Chateauneuf, 1976; Paris 1981) led to the conclusion that the upper part of the Plougastel and the base of the Landévennec Formations belong to the Lower Lochkovian. The vertical range of $D$. lanveocensis covers the lower part of the Eisenackitina bohemica Biozone. The same result is obtained by the correlations based on the distribution of the spiriferid brachiopods. The succession containing the Dimerocrinites lanveocensis belongs to the Howellella mercurii Biozone corresponding to the Lower Lochkovian. The study of the distribution of the dimerocritid columnals in Normandy, North of Rennes and in the Laval syncline corroborates this stratigraphical range based on spiriferid and chitinozoan biozones. The columnals of $D$. lanveocensis are found in the lower part of the Eisenackitina bohemica Biozone (Paris, 1981; Paris et al., 2000).

Recent investigations carried out in the Central Iberian Zone of Portugal have brought new data for correlations with the Armorican massif. In the Valongo syncline, the section to the South of São Félix de Laundos is composed of cycles of grey to dark silts or shales alternating with white to yellow sandstones containing some ferruginous and phosphatic layers. Columnals and isolated cup plates have been collected in these beds, where Platyorthis monnieri has been also found. The crinoid ossicles belong to Dimerocrinites lanveocensis and Diamenocrinus sp. A indicating a Lower Lochkovian age for the lower part of the Telheiras Formation. Isolated cup plates of $D$. lanveocensis have been collected by Delgado (1908) in the vicinity of São Mamede (Portalegre syncline). The exact position of the fossiliferous level in the red and white sandstone succession of the so called "Grès supérieurs" has not been established. Recent field studies around São Mamede, Serra de Selada, and Serra Fria (Portalegre syncline) failed to obtain new material from the white and yellow sandy facies. Nevertheless, the presence of the species allows correlations between the Portalegre and Valongo synclines and the Devonian formations of the Amorican massif.

Dimerocrinites sartensis $\mathrm{n}$. sp. occurs higher in the Lower Devonian succession in Normandy and in the Laval syncline. The species has been collected in the La Haye-du-Puits and Gahard Formations but it has not yet been discovered in the western part of the Armorican massif (Brest and Crozon areas). The columnals and isolated plates are associated with spiriferids of the Howellella lineage such as $H$. knetschi and $H$. cortazari. These species are indicative of a late Early Lochkovian age. As pointed out in the evolutionary trends, the regression of the epifacet on the columnals accelerated during the Late Lochkovian. The vestigial epifacet is characteristic of $D$. oehlerti collected in bed S92 in the type section of the Pointe de l'Armorique, a few meters above the Lochkovian/ Pragian boundary (S80-82). The vertical distribution of the species in the Saint-Céneré Formation is not established. Information on the specimens collected by earlier workers in the sections of the Laval syncline is not detailed enough for precise correlations.

\section{PALEOBIOGEOGRAPHY}

The paleobiogeographical patterns of the dimerocrinitid and scyphocrinitid crinoids have been 


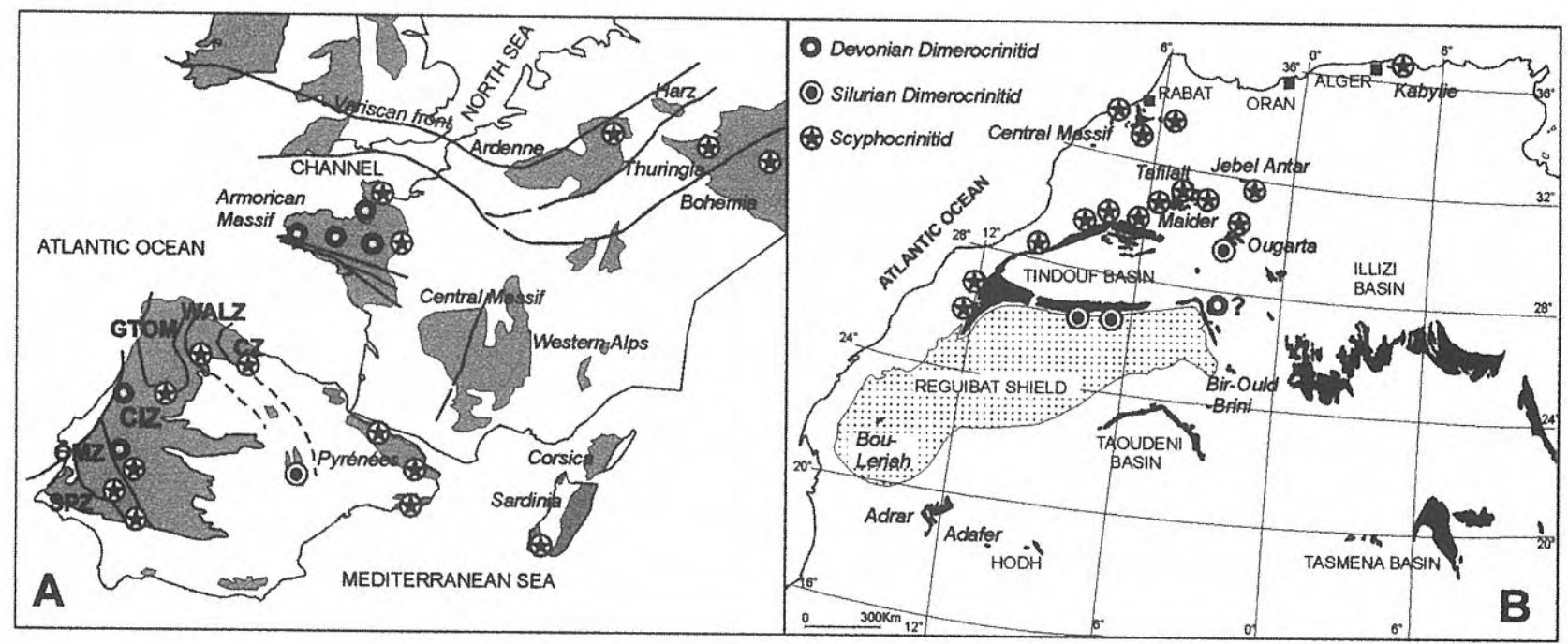

Figure 7. Geographical distribution of dimerocrinitid and scyphocrinitid columnals. A: South-Western Europe with main Hercynian massives (shaded); B: North Africa with Devonian outcrops in black.

briefly outlined from avalaible North Gondwana data (Le Menn, 1999). In the Ibero-Armorican domain, the Upper Silurian and Lower Devonian are characterized by fine detrital sedimentation with dominant benthic faunas of brachiopods, corals, bryozoans, and crinoids mainly represented by dimerocrinitids. This type of facies is often opposed to the shaly calcareous deposits containing graptolites, nautiloids, and scyphocrinitids considered as more distal on the shelf. The new data obtained during the last years in the Ibero-Armorican domain show that there is no clear-cut limit between these two crinoid biofacies.

In the Western part of the Armorican massif, from the Crozon Peninsula to the North of Rennes, the dimerocrinitids are the most frequent crinoids encountered in the Early Lochkovian-Pragian time interval. At present no scyphocrinitid ossicles have been identified in these areas (Fig. 7). On the eastern border of the Armorican massif, three occurrences have been recorded. In the Laval syncline, the scyphocrinitid columnals are present in the locality Moulin de Régereau in Pridolian sandstones dated by Urnochitina urna (Plaine, 1976; Paris, 1981) and in the Saint-Pierre-surErve section in bed SPE2 which is assigned to the Early Lochkovian on the basis of chitinozoans (D'Erceville, 1979; Paris, 1981). In Normandy, scyphocrinitids have been discovered in association with Monograptus uniformis (Jaeger and Robardet, 1973) in an isolated outcrop a few meters below the base of the typical "Platyorthis monnieri sandstones" of the la Haye-duPuits Formation in which Dimerocrinites lanveocensis and higher D. sartensis n. sp. columnals are present in the Saint-Germain-sur-Ay section. This distribution of the scyphocrinitids found in levels below the dimerocrinitids and never in co-occurrence, raises a question on their vertical range. The development of $D$. lanveocensis may be interpreted as starting after the extinction of the scyphocrinitids, which are ubiquitous in Late PridoliEarly Lochkovian time interval. The vertical range of the scyphocrinitids extends into the base of the Upper
Lochkovian as documented by the last occurrence of isolated plates, columnals, and arms in level DK29 of the Dkissa section in Ougarta (Le Menn, 1997). The limit between the Lower and the Upper Lochkovian is based on the graptolite and tentaculitid species found in level DK27 (Paris et al., 1997). Thus both crinoid groups coexist in the Lower Lochkovian and their distribution is regulated by environmental conditions or paleogeographical configuration. The scarce occurrences of scyphocrinitids in the terrigenous deposits may be interpreted as an episodic incursion of the floating crinoids into a protected shelf.

In the Iberian peninsula, the dimerocrinitids are present in Aragón (Wenlock-Ludlow), in the Valongo and Portalegre synclines of the Central Iberian Zone (Lower Lochkovian). Until now they have not been identified in Lochkovian sandstones of the Furada, San Pedro, Carazo and Luesma formations, although they may be potentially present in such an environment (Fig. 7). As on the eastern border of the Armorican massif, occurrences of scyphocrinitid columnals have been mentioned in the Carazo Formation of the Palencia area (Jahnke et al., 1983; Henn and Jahnke, 1984). A new study of columnals stored in Delgado's collections reveals that scyphocrinitids are also present in the Portalegre syncline near São Julião, but the precise stratigraphical position remains unknown. The neighbouring Ossa Morena Zone displays a typical scyphocrinitids biofacies, particularly in the South-East in the Valle syncline (Jaeger and Robardet, 1979; Racheboeuf and Robardet, 1986; Oczlon 1989; Robardet et al., 1998). In North Africa, accumulations of scyphocrinitid ossicles are widespread in Pridolian and lower Lochkovian limestones, with exception of the southern limb of the Tindouf basin along the northern side of the Yetti Eglab massif (Reguibat shield). Above the so-called "dalle à Encrines" with D. aragonensis n. sp., there is no evidence of scyphocrinitids in the sections investigated from West to East (Bitam et al., 1996; Gourvennec et al., 1997). 
This overview on the dimerocrinitid distribution in the North Gondwana points out that they are related to sandy environments deposited in proximal position on the shelf. In the Upper Pridoli and the Lower Lochkovian, the episodic occurrences of scyphocrinitids in the IberoArmorican successions suggest that a protected shelf or interior epicontinental sea may be inferred for the dimerocrinitid paleoenvironment.

\section{CONCLUSIONS}

Dimerocrinitid crinoids are present in North Gondwana from the Wenlock to the Lower Pragian. Although complete crowns are scarce, the main features of the species have been established on dissociated plates and columnals. They display significant characteristics clearly different from those of the Laurussian forms: large size, stout thecal plates, and developed epifacet. A maximum size of the theca is recorded in the Lower Lochkovian where the dorsal cup height reaches over one hundred millimetres with thick plates. Evolutionary trends observed on columnals along this time interval show a development of the articular structures followed by a reduction of the epifacet. Significant epifacetal regression took place during the Upper Silurian-Lower Lochkovian.

The vertical distribution of the species in the Wenlock-Pragian interval is discontinuous with a lack of data in the Upper Ludow and Pridoli. The high frequency of dissociated columals and plates of D. lanveocensis, which appears close to the Silurian/Devonian boundary, may be used to characterize the lowermost Devonian in the Ibero-Armorican domain. The presence of D. oehlerti in beds overlying the Lochkovian-Pragian limit is also of interest for correlations.

These dimerocrinitid species with a wide geographical distribution, extending from South Algeria to the Armorican massif, may be considered as typical elements of the North Gondwanan fauna. Their association with other benthic invertebrate groups in terrigenous sediments is indicative of a proximal paleoenvironment in protected epicontinental sea in contrast with the distal, open-shelf scyphocrinitids biofacies.

\section{ACKNOWLEDGEMENTS}

We grateful aknowledge the Instituto Géologico e Mineiro de Portugal and the Service géologique d'Algérie for their support during field work. We are greatly indebted to the ICCTI of Portugal and the Ambassade de France au Portugal for their grants which supported our research. We thank also F. Paris for his data on chitinozoan biozonation.

\section{REFERENCES}

Bitam, L., Gourvennec, R. et Robardet, M. 1996. Les formations paléozoïques anté-carbonifères du sous- bassin de Djebilet (flanc sud du Bassin de Tindouf, Nord-Ouest du Sahara algérien). Mémoires du Service Géologique d'Algérie, 8, 91-111.

Boumendjel, K., Brice, D., Copper, P., Gourvennec, R., Jahnke, H., Lardeux, H., Le Menn, J., Mélou, M., Morzadec, P., Paris, F., Plusquellec, Y. et Racheboeuf, P. 1997. Les faunes du Dévonien de l'Ougarta (Sahara Occidental, Algérie). Annales de la Société géologique du Nord, (2) 5, 89-116.

Carls, P. 1965. Jung-silurische und unterdevonische Schichten der östlichen iberischen Ketten (NE-Spanien). Inaugural-Dissertation Würzburg, 1-155.

Carls, P., 1971. Stratigraphische Übereinstimmungen im höchsten Silur und tieferen Unter-Devon zwischen Keltiberien (Spanien) und Bretagne (Frankreich) und das Alter des Grès de Gdoumont (Belgien). Neues Jahrbuch für Geologie und Paläontologie, Monatshefte, 4, 195-212.

Carls, P. 1977. The Silurian-Devonian boundary in northeastern and central Spain. The Silurian-Devonian boundary. IUGS Series A (Stuttgart), 5, 43-158.

Collin, L. 1912. Etude de la région dévonienne occidentale du Finistère. Imprimerie Bourgeon, Brest, 1-470.

D’Erceville, M.A. 1979. Les spores des formations silurodévoniennes de la coupe de Saint-Pierre-sur- Erve (Synclinorium médian armoricain). Palaeontographica, $B, \mathbf{1 7 1}, 79-121$.

Delattre, C., Jérémine, E., Laffitte, P., Pruvost, P. et Sandrea, A. 1951. Révision des feuilles de Lannion, Morlaix et Tréguier au $80000^{\circ}$. Bulletin de la carte géologique de France, 49 (232), 48-55.

Delgado, J.F.N. 1908. Système silurique du Portugal. Etude de stratigraphie paléontologique. Commission du Service géologique du Portugal, 157-173.

Deunff, J. 1980. Le paléoplancton des Grès de Landévennec (Gédinnien de la rade de Brest, Finistère). Etude biostratigraphique. Geobios, 13, 483-539.

Deunff, J. et Chateauneuf, J.J. 1976. Sur la présence d'un riche microplancton siluro-dévonien à Acritarches, spores et Chitinozoaires au sommet des schistes et quartzites de Plougastel (rade de Brest, Finistère); son intérêt stratigraphique. Géobios, 9, 337-343.

Gévin, P. 1960 . Etudes et reconnaissances géologiques sur l'axe cristallin Yetti-Eglab et ses bordures sédimentaires. Première partie: bordures sédimentaires. Bulletin du Service de la carte géologique d'Algérie, nouvelle série, 23, $1-368$.

Gourvennec, R., Bitam, L. et Robardet, M. 1997. Les formations paléozoïques anté-carbonifères du sousbassin de l'Iguidi (Flanc sud du bassin de Tindouf, nordouest du Sahara Algérien). Bulletin du Service Géologique d'Algérie, 8, 135-148.

Henn, A.H. und Jahnke, H. 1984. Die palentinische Faziesentwickelung im Devon des kantabrischen Gebirges. Zeitschrift deustche geologische Gesellschaft, 135, 131-147.

Jaeger, H. et Robardet, M. 1973. Découverte de Monograptus uniformis Pribyl, Graptolite gédinnien, dans les "schistes et quartzites siluro-dévoniens" du Cotentin (Normandie, France). Comptes rendus de l'Académie des Sciences, Paris, 277, 2129-2132. 
Jaeger, H. et Robardet, M. 1979. Le Silurien et le Dévonien basal dans le Nord de la province de Séville (Espagne). Geobios, 12, 687-714.

Jahnke, H., Henn, A.H., Mader, H. und Schweineberg, J. 1983. Silur und Devon im Arauz-Gebiet (Prov. Palencia, $\mathrm{N}-$ Spanien). Newsletter on stratigraphy, 13, 40-66.

Legrand P. 1969. Découverte de Graptolites entre Gara Djebilet et Aouinet Bel Egra (Synéclise de Tindouf, Sahara Algérien). Bulletin de la Société d'Histoire naturelle de l'Afrique du Nord, 59, 115-126.

Le Menn, J. 1980. Les Crinoïdes. In: Les Schistes et calcaires de l'Armorique (Dévonien inférieur, Massif armoricain) (Coord. Y. Plusquellec). Mémoires de la Société géologique et minéralogique de Bretagne, 23, 249-271.

Le Menn, J. 1985. Les crinoïdes du Dévonien inférieur et moyen du Massif armoricain. Mémoires de la Société géologique et minéralogique de Bretagne, 30, 1-268.

Le Menn, J. 1987. Growth patterns and evolutionary trends of Devonian crinoid columns. Geobios, 20, 811-829.

Le Menn, J. 1997. Crinoïdes. In: Boumendjel, K., Brice, D., Copper, P., Gourvennec, R., Jahnke, H., Lardeux, H., Le Menn, J., Mélou, M., Morzadec, P., Paris, P., Plusquellec, Y. et Racheboeuf, P. Les faunes du Dévonien de l'Ougarta (Sahara Occidental, Algérie). Annales de la Société géologique du Nord, Lille, (2) 5, $89-116$.

Le Menn, J. 1999. Biogeography of crinoid columnals: some aspects in the Upper Silurian and Devonian. IGCP 421SDS Meeting Morocco (Errachidia, 23-30 april 1999.) Abstract Book, 31-33.

Oczlon, M. 1989. Fazies und Fauna im Silur und Devon des "Valle" (Provinz Sevilla, SW Spanien). Diplomarbeit Universität Heildeberg, 1-86.

Paris, F. 1981. Les Chitinozoaires dans le Paléozoïque du Sud-Ouest de l'Europe. Mémoires de la Société géologique et minéralogique de Bretagne, 26, 1-412.
Paris, F., Boumendjel, K., Morzadec, P. et Plusquellec, Y. 1997. Synthèse stratigraphique du Dévonien de l'Ougarta (Sahara Occidental, Algérie). Annales de la Société géologique du Nord, (2) 5, 116-122.

Paris, F., Winchester-Seto, T., Boumendjel, K. and Grahn Y. 2000. Toward a global biozonation of Devonian chitinozoans. Courier Forschungs-Institut Senckenberg, Frankfurt-am-Main, 220, 39-55.

Phillips, J. 1839. Encrinites and zoophytes of the Silurian System. In: Murchison, R.I. The Silurian System. Murray ed., London, 670-675.

Plaine, J. 1976. La bordure sud du synclinorium paléozö̈que de Laval (Massif armoricain). Stratigraphie, volcanisme, structure. Thèse $3^{\circ} \mathrm{Cycle}$, Université de Rennes, 1-229.

Plusquellec, Y. 1992. Géologie de la presqu'ile de Plougastel. Penn ar Bed, 144-145, 1-64.

Pruvost, P.1914 . Observations sur les terrains dévoniens et carbonifères du Portugal et sur leur faune. Comunicações da Comissão do Serviço Geológico de Portugal, 10, 1-10.

Pruvost, P., Jéremine, E. et Le Maître, D. 1946. Révision de la feuille de Pontivy au $80000^{\circ}$; Région de Gouarec. Bulletin de la carte géologique de France, 46 (221), 213224.

Racheboeuf, P. et Robardet, M. 1986. Le Pridoli et le Dévonien inférieur de la Zone d'Ossa-Morena (SudOuest de la Péninsule ibérique). Etude des Brachiopodes. Geologica et Palaeontologica, 20, 11-37.

Renouf, J.T., 1972. Brachiopods from the Grès à Orthis monnieri Formation of North-Western France and their significance in Gedinnian/Siegenian stratigraphy of Europe. Palaeontographica, A, 139, 89-133.

Robardet, M., Piçarra, J. M., Storch, H.P., Gutiérrez-Marco, J.C. and Sarmiento, G.N. 1998. Ordovician and Silurian stratigraphy and faunas (graptolites and conodonts) in the Ossa Morena Zone of the SW Iberian Peninsula (Portugal and Spain). Temas Geológico-Mineros ITGE, 23, 289-318. 